\title{
Archival Description and Automation: A brief history of going digital
}

\section{Introduction}

This paper seeks to set the scene for this special issue on Born Digital Description by providing a high level overview and a skeleton chronology of its origins in the United Kingdom. The main source used to produce this overview/chronology has been earlier pages of this journal, but this has been supplemented by other secondary sources, including the work of Michael Cook, Robert Chell, Jennifer Hogarth and others. A richer picture could undoubtedly be produced if sources, such as the voices of those who were responsible for the innovations being described below, were consulted. However, it is a step in the right direction and it is hoped that this initial overview may encourage further steps in the direction of more detailed histories.

In the UK, it would certainly appear that the idea of description (meant here in the sense of the process and product of descriptive practice within archival institutions) going digital was starting to form during the 1960s. For example, it was reported that, at the Conference of the Society of Archivists held in Newcastle upon Tyne in 1964, a paper was presented by Nigel Cox of Newcastle University Computing Laboratory on 'The computer as an aid to archive administration and historical research'. ${ }^{1}$ This paper led those listening to 'happy visions of indexes being compiled and sorted by machine'. ${ }^{2}$ Then again, later in the same year, at the Society's Annual General Meeting, a discussion was held on the subject of 'Automation and Archives' at which Hugh Taylor 'County Archivist of Northumberland [spoke] on discussions which he and several colleagues in the North East have been holding on the subject'. ${ }^{3}$

Nor was it just all talk during this decade. At a meeting held at the Institute of Historical Research in December 1965, Christopher Roads, then Deputy Director and Keeper of the Department of Records at the Imperial War Museum, was able to report that the museum had; 'for the past two and a half years been devising a form of automatic data retrieval' with one aim being 'the semi-automatic production of select catalogues of sections of our film and photographic collections'. ${ }^{4}$ As the decade progressed, the subject remained a live one; at a symposium held in Cambridge in January 1968 on 'The Management of Records', 'Dr Needham gave a paper on the use of computers in information retrieval'; ${ }^{5}$ and, at the Society of Archivists' Annual General Meeting in 1969, Kenneth Darwin, Deputy Keeper of the Records, Northern Ireland spoke 'on his investigations into the possible application of computers to the production of indexes and finding aids'. ${ }^{6}$ It is with the 1960 s then that this narrative will begin.

It will end with the early 1990s, just before the start of the internet phenomenon as we know it today. This may appear to be an odd choice, given that it would be fairly easy to make the case that the rate at which description went digital increased very markedly after this time. Certainly it is to the later 1990s that we have to look for, for example, the arrival of Encoded Archival Description and the highly influential (in the United Kingdom) report, Archives Online, produced by the National Council on Archives in 1998. However, to address such developments comprehensively, would require at least another article. More practically, 1992 and 1993 saw the publication of two surveys, one of computer applications, and one of automated practice in UK record offices, allowing us to finish our picture on fairly firm and evidenced ground. This article concentrates then on building the ground to underpin any future examination of later periods and, along the way, it will try to sketch out how the vision of 'going digital' changed over time, in line with advances and changes in the 
underlying technological landscape. And also how archivists reacted to these changes and how they tried to cope with what was coming.

\section{Envisioning 'going digital'}

The first way in which description was envisioned as going digital was in terms of 'using the computer to provide finding aids, not to do individual searching in records'. ${ }^{7}$ It was perhaps just about seen as feasible that you could 'extract specific information for particular searchers if this appeared to be worthwhile', but it was nonetheless envisaged that 'the normal end product' arising from the process of using computers in description would be 'a rearranged print-out of your existing catalogues'.8

One of the main drivers behind this vision was the fact that it offered the potential for archivists to go some way to deal with, what Kenneth Darwin, speaking in 1969, called 'an explosive demand in my own office for better searching aids' and the realisation that existing searching aids 'were deficient and not suited to the average ill-informed but reasonably intelligent searcher whom we were in process of successfully encouraging to come and use the Record Office'. ${ }^{9}$ Darwin's sense was that 'Searchers in our record offices are no longer going to be content with antiquated systems of information retrieval, they are going to demand the sort of service they get elsewhere and we have to prepare ourselves to give this'. ${ }^{10} \mathrm{~A}$ solution to this problem, tried and abandoned (as being too time consuming) in his own office had been the construction of 'Sectional Guides or Lists';11 essentially subject guides drawing together information on, for example, maps, or collections of landed estate records. Darwin, and others, saw the potential in being able to put information about their holdings into a computer and thereby being 'able to pull it out in 25, 2,500 or 25,000 different ways', adding that;

From an archivist's experience of demands made in search rooms [...] we should know what part of our records and what information in our records is most needed [...] It is therefore possible for us to do selective retrieval and print out information to give us indexes, chronological listings, subject listing and arrangements of documents and guides of all sorts. ${ }^{12}$

By 1969, this vision had already started to be realised - Darwin was influenced by both the Imperial War Museum work mentioned earlier and that of the Mormons in Salt Lake City - and in 1971, Carl Newton reported that East Sussex Record Office had completed the successful production of an archive catalogue by computer' which was believed to be 'the first to be so produced in England'. ${ }^{13}$

East Sussex Record Office were later seen to be distinguished in this early work, because it was, in the main, being carried out at this early stage by national, rather than local institutions. ${ }^{14}$ At the Public Record Office, for example, work had been carried out both; to develop what became known as the PROSPEC system (reported in a 1972 article in the Journal of the Society of Archivists), ${ }^{15}$ and experiments had been undertaken since the mid-1960s in connection with automating indexing. ${ }^{16}$ These experiments eventually led to a joint PRO/SRO (Scottish Record Office) consultancy and further experiments with the PRECIS system in the mid-1970s. ${ }^{17}$

Bringing some coherence to these various and individual efforts, the Computer Applications Committee of the Society of Archivists, which was established in January 1973, provided in 1974 a summary of 'computer applications existing or planned in record offices in the United Kingdom'. ${ }^{18}$ They chose to distinguish between the impact of these applications 'in three areas of archival activity: (1) in record office management; (2) in records management; and (3) in the preparation of 
finding aids' ${ }^{19}$ Given that the focus of this article is on description, (3) is clearly of most relevance, but it is also noticeable that one of the two subdivisions of (2) - 'the use of computers in the management of a records centre' (the other being 'the selection, storage and use of records on computer media') - is also relevant. ${ }^{20}$ Indeed the Committee noted under this subdivision that in all the cases it discussed 'the primary purpose of the computer is to provide a finding aid to assist in the retrieval of information from records in the records centre'. ${ }^{21}$ Two of the applications mentioned in this regard were within business environments, but the third was East Sussex Record Office, where the same system (ARCAIC) was mentioned in connection with both (2) and (3). It is tempting to wonder if things might have gone differently at this early stage, when the boundaries between systems were still emerging, if boundaries such as that between records management (and centres) and archives management (and record offices) had not already been so entrenched. Certainly when discussing applications in records management, the Committee makes the tantalising suggestion that in the future 'it will be worth including in such systems [computerised registry systems or general information systems which incorporate current records] provision for a disposal date and continuing the system in use for general purposes through the intermediate stage and even, if the system is adequate, into the archives proper'. ${ }^{22}$

The activity reported in the 1974 summary was very limited, but it would also appear that what was being envisioned by description going digital was starting to expand beyond simply the production of finding aids - 'conventional lists or indexes in some form of print-out'. ${ }^{23}$ The Committee noted that 'Elsewhere, especially in West Germany and Italy, research is being directed to on-line interrogation of computer-held data bases. ${ }^{\prime 24}$ To understand how 'cutting edge' such research might have seemed, it is worth remembering the state of computer technology in the 1970s. As the Committee noted, there were by 1974 alternatives to punched cards as an input medium, but for 'Modern systems' the norm was still very much 'input on punched paper tape or magnetic tape'. ${ }^{25}$ Computers were still basically main frames and data tended to be batch input at remote computer bureaus. Nevertheless the Committee was starting to recognise a vision of digital description in which readers might sit 'at terminals consulting records' and in which 'On-line interrogation of a data base may be a useful tool for the archivist himself', even if they still found these ideas unlikely to various degrees. ${ }^{26}$

The realisation of even this limited vision was still some way off, but the 1970s saw continued effort and activity using the available technology. In 1977, it was reported that 'the computer has at last come to Westminster' and brief details were given of the use of 'IBM's STorage And Information Retrieval System (STAIRS) linked with their Advanced Text Management System (ATMS)' at the House of Lords Record Office. ${ }^{27}$ In 1978, details of work involving the PRECIS system to produce a subject index to the holdings of West Devon Record Office were announced. ${ }^{28}$ And finally, in a packed volume of the Journal of the Society of Archivists in 1979, not one, but three computer applications were reported; one at St John's College Archives, ${ }^{29}$ CAR - the Dyfed records management system, ${ }^{30}$ and ARMS, also designed in a records management context in Tyne and Wear County Council. ${ }^{31}$

Further details of a number of these early systems can also be found in Michael Cook's 1980 edition of Archives and the Computer..$^{32}$ This volume sought to give 'a general introduction to the computer and its possibilities for operating as a tool in archival management' ${ }^{33}$ It structured the bulk of its discussion into three broad categories, but these were slightly different to those used earlier by the Computer Applications Committee in 1974. Machine readable archives were no longer seen as a subdivision of records management, but were treated as a subject (and a chapter) in their own right, the other two being; systems for records management and systems for archival description, retrieval and management. This last bringing together two previously separate categories - record office 
management and the preparation of finding aids. There is then a sense in which, by the 1980 s, the vision was becoming not just one of specialised systems for specific tasks (such as the production of finding aids) but also one of integrated systems potentially supporting the running of entire services. Cook discussed how;

Archivists are not accustomed to regard their services as similar in kind to those offered by, for example, manufacturing industries. Yet from a systems point of view, an archives office has many of the same characteristics as the business control of such an industry. [...] It will be seen, then, that an archives office can organize itself around a central data base just as a business organization can. ${ }^{34}$

Then again this idea of integration could be taken even further, since, as Cook also noted; 'the data base of one office may, if it is suitably structured, be linked with the data base of one or more other offices, so as to form a network. National or regional networks for the storage, retrieval and publication of archival data are a real possibility'. ${ }^{35}$

This widening of the vision at this time was supported by fact that computers more generally were becoming less distant. As Cook notes alternatives to batch working and input on punched tape or cards or magnetic tape were becoming more common and he details both teletypes and online input/output through a (then) new device known as a VDU or Visual Display Unit, 'similar to a television screen, together with a typewriter keyboard'. ${ }^{36}$ With the appearance of such technologies, the idea of online interrogation of databases sitting at a terminal in the record office (whether by staff or users) did not seem quite so fanciful. Connected to this development, Cook also notes the arrival of microcomputers and their word-processing function. ${ }^{37}$ To gauge the impact of such developments on the automation of description, it is only necessary to compare this first edition of Archives and the Computer with the second, published in 1986. A new era of computing was coming and many of the first wave of systems would not ride it out; by 1980 it was already being reported that the pioneering ARCAIC system developed in the early 1970s at East Sussex Record Office was 'no longer in use'. ${ }^{38}$

In drawing the comparison with 1986, we will focus on those applications described in the chapter on 'Systems for Archival Description, Retrieval and Management'. In 1980 three UK based systems were described in this section; PROSPEC (at the Public Record Office), STAIRS (at the House of Lords Record Office) and ARCAIC (at East Sussex Record Office, although already abandoned). In 1986, PROSPEC remains and STAIRS is mentioned briefly, with a note that the use of it the House of Lords Record Office had ceased due to 'financial constraints', but the rest of the chapter is more or less completely new. ${ }^{39}$ Cook starts by discussing two 'systems for general utility in archival description [...] the GOS package of the Museum Documentation Association (MDA), and PARCH, a system developed from scratch by the Glasgow University Archives (GUA)'. ${ }^{40}$ Both these systems are reported as having been 'first based on a central mainframe, and later developed for microcomputers', but whereas GOS was reported as having been in use for archival material at the British Antarctic Survey (although soon to be 'dropped in favour of STATUS'), Greater London Record Office, National Maritime Museum and St John's College Cambridge (who had been running a version of GOS known as GOSLING since 1977), PARCH was only then in use at Glasgow University Archives. ${ }^{41}$ The other main systems of note appear to have been; FAMULUS, applications of which had 'been noted at the Modern Records Centre, Warwick University, at the Rutherford Appleton Laboratory, and at the Northwest Sound Archive' and STATUS, the application of which at the University of Southampton was written up in the Journal of the Society of Archivists. ${ }^{42}$ 
It would appear that all these systems still had their origins in the pre microcomputer era, and that the mainframe was still very much a part of the picture. At Southampton, for example, data may have been prepared on three BBC microcomputers, but once finalised, it was then transferred on floppy disc for uploading to the University's mainframe. ${ }^{43}$ Cook does report that 'Some archive services have chosen to adopt database management software which is now available for microcomputers' in particular mentioning dBase 2 and 3 , but it is clear that the PC (personal computer) revolution ushered in during the 1980s had a slow and steady, rather than an immediate dramatic impact on the automation of description. ${ }^{44}$ Nonetheless, an impact was felt, such that Cook, looking back in 1986, to compare the situation he described in his 1980 book with that found in a survey he undertook with Rachel Bartle in 1982 stated that 'A feature of this [1982] report was that a majority of systems noted had been introduced since 1980, and that interactive and microcomputer schemes were beginning to predominate'.$^{45}$ Then again, that there was some feeling of change towards more 'everyman' use of computers at this point is perhaps indicated by the fact that it was in 1986 that the Computer Applications Committee of the Society of Archivists chose to wind itself up, to be replaced instead by a Computer Users Group (soon afterwards to become the Information Technology Group). ${ }^{46}$

It was the Information Technology Group that published in 1992, one of the snapshots with which our chronology ends. Based on returns made to the group between 1988 and 1991, it presents a picture of increasingly widespread use of increasingly more everyday office applications in archives, so much so that it was necessary to note in the preface that;

Although many offices now use wordprocessing software and computers in their everyday work, these applications have not been included in the directory unless respondents stated that the software was being used for a specific non-wp application. The wp entries have, however been included in the indexes of applications and software in order to provide a more comprehensive picture of the overall use of computers in archives. ${ }^{47}$

The categorisation used in the directory is indeed a strange mix of general types of computer application and specific archival functions, consisting of; ACC Accessioning, ACTS Accounts, CAT Cataloguing, COMMS Communications, DAT Database, DTP Desktop Publishing, IND Indexing, INT Integrated archive system, LISTS Listing, PRC Process control, RM Records management, SPR Spreadsheet WP Word processing. This clearly led to some confusion and so, in the directory, a Wills index is coded as both DAT and IND by different record offices and LISTS is assigned by Walsall Local History Centre to the description 'Mailing list for publications' ${ }^{48}$ Complete reliance cannot therefore be put on the accuracy of the categorisation, but applications listed under CAT, IND and LISTS include both the possibly unfamiliar; RD-QUICK, TINLiB, ASSASSIN, and possibly the more familiar; CAIRS and MODES. There is also a fair number of then common database (DBase) and word processing packages (Word Perfect, Wordstar etc).

The directory clearly demonstrates that computing was becoming more mainstream within archives, but it does not give a very rich picture of how the various applications it lists were being used and for what. Fortunately it can be supplemented by a survey of automated practice which was carried out in 1992 and published in 1993. ${ }^{49}$ In this publication 18 case studies (limited mainly to the South East of the UK) are described in detail, although it is noted in the preface that it had proved impossible to completely standardise the reporting format on each of these eighteen. ${ }^{50}$ The authors make the valid point that 'It could be concluded that this lack of standardisation is in itself a true reflection of the present diverse range of automation within the profession'. ${ }^{51}$ Despite this diversity, there are however a few generalities drawn by the authors of the report. For example, it was noted that, 'Virtually all the systems visited were as yet for staff use only' and also that 'The possibility of data 
exchange was also raised [...] the question had not usually been considered'. ${ }^{52}$ By the early $1990 \mathrm{~s}$ then, the visions of producing finding aids using computers, and of online interrogation of databases (at least by staff) had been realised, but the sense does seem to have remained that more fundamental shifts were still ahead. As Christopher Kitching noted in a RAMP study on 'The Impact of Computerization on Archival Finding Aids' published in 1991;

the computer is compelling archivists to broaden their horizons in the management and exploitation of information about archives, and in particular to reconsider what they mean by the term 'finding aid' in the context of computerisation. ${ }^{53}$

\section{Dealing with 'going digital'}

Now that we have established the broad chronology of the development of the use of computers in archives, we turn instead to the question of how archivists reacted to and tried to cope with the changes they were facing. In the same volume mentioned above, Chris Kitching offered the following verdict on his fellow archivists, looking back over the then recent past;

On the whole, archivists were slow to respond to the challenges of computers. They lacked the resources to become deeply involved at an early date (when virtually all computer applications were on expensive mainframes) as well as the training to enable them to see the potential, alongside the problems, of computers. Their first steps were tentative and sceptical, ${ }^{54}$

Personally I feel this may be a little too negative, and would like to suggest a more positive view. To be sure there were issues with resources, but those with them (such as the national institutions or those such as East Sussex Record Office with access to central computing services) were not slow to respond and were engaging with computing even in the very early days of punched card input and batch working. Then again, recognising this issue with resources, there was even an early attempt to effect what would today be called a shared services model in this area using PROSPEC, the PRO system mentioned earlier.

A report of the Society of Archivists' Annual Conference in 1979 details how:

The Computer Applications Committee discussed the possible wider use of PROSPEC in 1973 and, following an article in the Journal and further discussion at the Winchester Conference in 1974, a questionnaire was sent to heads of repositories about the pilot project in 1975. The project ran during 1977 and 1978 with grants from the Society, the British Library Reference Division and ten participating repositories. ${ }^{55}$

In the article mentioned in this quote, the Committee had stressed that;

there are distinct advantages in archivists co-operating in the computer field in order to reduce costs and to make the best use of the expertise which does exist. Such co-operation might take the form of a consortium and the best basis for such a consortium would seem to be the Society. ${ }^{56}$

Moreover the discussion at the Winchester Conference (also mentioned in the above quote) may well have been in response to a paper (presented by Lionel Bell and later published in the Journal of the Society of Archivists) which proposed that;

in the era of mass-production in which we live the rather peculiar needs of archivists will increasingly fail to be met unless we join together in expressing those needs and, equally, 
unless we join forces we may not be able to exploit to the full for archival ends the technology which is the hallmark of our era. ${ }^{57}$

The project to take forward this co-operative effort in the computer field was known as PROSPEC-SA (SA standing for the Society of Archivists). It does not however, appear to have been a great success and the final report identifies a number of issues not least the overrun of the timetable, which led to, amongst other things, 'insufficient time to obtain the reactions of the participants before the deadline for this report' ${ }^{58}$ Their verdict on the project is not therefore easily accessible, but other problems identified in the report were around indexing terms and problems with sorting by local reference code.

The state of 1970s technology certainly impeded what archivists (like everyone else) were able to do with computers, but they were not slow to come together to address the issue and to explore the possibilities of co-operation in the field. The early discussions at conferences and meetings in the 1960s, continued and developed into the 1970s. For example, a course (jointly arranged by the Society of Archivists and the Business Archives Council) was held on 'The Archivist and the Computer' in May $1971 .{ }^{59}$ Then again, UK archivists played a role in the International Council on Archives Working Party on the Implications of Automatic Data Processing for Archival Management, which met in Spoleto in $1972 .{ }^{60}$ This group later became known as the Automation Committee and it produced its own bulletin, ADPA which contains many reports of early efforts, both in the UK and internationally, to explore the new possibilities opening up. ${ }^{61}$ Finally, as we have seen, 1973 saw the establishment within the UK of the Computer Applications Committee, which sought to drive the agenda forward throughout the 1970s and into the 1980s. One of the main ways in which archivists responded to the challenges of computers then, was to seek to cooperate and learn from each other. And yet, it was seemingly still possible to state, in 1993, that 'archivists are perhaps working too much in isolation, without an overview of what is happening in the profession as a whole' ${ }^{62}$

This dissonance in the evidence for both co-operative forums and action, and a sense of archivists 'working too much in isolation' is a subject worthy of further study. The reasons for the lack of an overview, given by those suggesting it, included; 'the profession's failure to initiate research in the field of IT, or to develop a suitable forum for the exchange of ideas'. ${ }^{63}$ The last again seems a little incongruous given what we now know, but the former does perhaps suggest a possible explanation. Further work would need to be undertaken to make the case watertight, but it could perhaps be argued that the profession did not initiate research in the field of IT, partly because it did not (and still does not) see IT as its field to initiate or innovate in, and partly because the cooperative effort in research and the exchange of ideas which it did initiate was rapidly diverted towards something it did see as very much in its field - archival description, descriptive practice and the standardization thereof. For example, at the Annual General Meeting of the Society of Archivists in 1975; 'Mr Roper stressed the importance of cooperation within the profession in the development of computer systems' but he also added that 'before this could be achieved there must be agreement on standards of terminology, procedures, style and formats - standards which could be drawn up by this committee' ${ }^{64}$ Then again, the problems raised in the report evaluating the early co-operative PROSPEC-SA system were not about the technology involved, but about indexing terms and the problem of dealing with diverse local reference codes. Perhaps the isolation in which archivists felt themselves to be working in 1993 was indicative more of their (self-imposed?) isolation from the field of IT and its concerns with the development of computer technology and systems rather than their isolation from working together per se.

Whatever the accuracy of this proposition however, it is clear that there is some kind of connection between the development of computer use in archives and efforts towards the standardisation of 
archival description. The connection can be seen in Roper's comments from 1975 quoted above. It can be seen in the fact that in the UK the nearest thing to a standard for archival description available before ISAD(G), namely MAD - A Manual of Archival Description - arose from the work of the Methods of Listing Working Party, one of whose aims appears to have been 'a full data standard for computerised archival description. ${ }^{65}$ It can also be seen by the fact that, in Christopher Kitching's 1991 RAMP study, the first areas mentioned in the chapter on 'Current Research and Development' are 'Standards for archival description in general' and 'Control of terminology and concepts'; the others being 'Data exchange formats', 'Networks' and last of all 'New technology' taking up a mere 4 pages out of 25. This last categorisation (which was based on an assessment of the areas of greatest concern to the international community of archivists in the early 1990s in turn based on questionnaire returns) gives a good impression of where the focus of the archival community had ended up as a result of computerisation. Yes, there was some interest in new technology, yes there was more interest in 'the means of communicating automated archival information nationally and internationally, through the development of data exchange formats and networks' but most of all, there was interest in 'the formulation of nationally and internationally agreed standards covering archival description including the control of terminology and authorities' ${ }^{66}$

Just as one of the main ways in which archivists responded to the challenges of computers was to seek to cooperate and learn from each other, another response was an increasing focus on the standardisation of archival description. It would be nice to see in this focus evidence of the sort of reconsideration mentioned by Christopher Kitching when he spoke of how; 'the computer is compelling archivists [...] in particular to reconsider what they mean by the term 'finding aid' in the context of computerisation' but there is a question to be asked about whether and to what extent such a reconsideration really took place ${ }^{67}$ In their consultation document for the wider UK profession, published in 1974, the Computer Applications Committee identified a number of problems, the first of which was standards. They wrote;

If the computer is regarded as a tool to be used by archivists and not as a master to control him, there is no reason to fear a decline in standards. It is up to the archivist to ensure that any computer application takes full account of professional standards [...] This means that the archivist must carefully specify his requirements at the design stage of a computer application and ensure it meets his standards ${ }^{68}$

Standardisation viewed through this lens is not so much about reconsideration as about reassertion, the reassertion of professional (and human?) ascendancy over computers as our tools and not our masters. Going on, and perhaps offering more hope of reconsideration, the Committee did add that;

This is not to say that we should impose our standards unquestioningly upon the computer. The planning of a computer application is an ideal time to examine archival practices and to ask whether they are necessarily the best of all possible alternatives [...]. It would undoubtedly help if as a profession we could achieve some measure of agreement on a standard terminology and on a standard of style and format for our finding aids. ${ }^{69}$

There are two ideas being linked here and it is the nature of that link that is perhaps under question. On the one hand there is the idea that we should question existing practices and examine alternatives. On the other is the idea that 'it would undoubtedly help' if we agreed on a standard. What or how would it help though? Would and did the movement towards agreement on a standard help the questioning of existing practices or would and did it help the archivist to 'specify his requirements at the design stage of a computer application and ensure it meets his standards' ${ }^{70}$ Is it the archivists or the computers who are controlling and driving the action here? There is of course 
a chicken and egg quality to this question and the answer as to the exact balance of power probably remains mute.

Thinking instead in terms of reconsideration rather than balance of power, I am in agreement with those who believe that there is still plenty of space for reconsideration of existing practices in response to changes in technology. ${ }^{71}$ For example, is it not time that we returned to a discussion about 'the construction and allocation of reference codes'. ${ }^{72}$ Gareth Haulfryn Williams attempted to start this discussion in 1990 and Adam Green joined in with some thoughts on 'reference codes and computer-based systems'. ${ }^{73}$ Some may scoff at the idea of anything written over twenty years ago saying anything of relevance to them today, but how often do the majority of us stop and think about all the work we expect our reference codes to do? Gareth Williams and Adam Green both did. However, whereas Gareth Williams did so from a position of suspecting that 'coding is regarded in some way as being beneath the notice of the skilled archivist', Adam Green weighed in from a position of being personally involved, as County Archivist of Somerset, with the design and development of one of the early attempts at an integrated archives system. ${ }^{74}$ Reading the two articles together then, different forms and degrees of reconsideration are apparent and perhaps the potential differences made by the computer on the thinking of the time can be gauged.

For example, Gareth Williams, noted that in his production of a set of suggested rules for reference codes; 'one omission [...] is any mention of the application of computers to handling, or indeed conceiving, reference codes'. ${ }^{75}$ In his article the human is the master and 'it is surely not unreasonable for us to demand that software be capable of handling any simple code we may devise'. ${ }^{76}$ Ultimately though, and despite a long and detailed exploration of aspects, uses and types of reference code, the suggested scheme for a reference code does not appear to differ very much from that traditionally used in record offices. By contrast, Adam Green, took the complexity exposed by Williams and held it up to the computer, suggesting that;

in theory the reference code can be reduced to its minimum role - citation. It becomes simply a unique identifier that can be used outside the system always to point to the same item within the system, regardless of changes within the system. That is what our users need: the rest is housekeeping. ${ }^{77}$

And so, whereas Williams was seen by Green as having pointed out 'that one of the less happy legacies of the Bedford-Essex school of archive management was to blur the boundaries of coding and arrangement' it took Green and his exposure to the control of 'the remorseless idiocy of the literal-minded computer' to fully comprehend, as he did later in his article, that 'in such a complex network of relationships structural and functional clashes are bound to occur'. ${ }^{78}$ Ultimately his suggestion was that;

In practice as well as in theory, the best approach is not to use existing reference codes as computer keys but rather to employ another code (typically a sequential number) for use within the computer. The reference code can then be treated as a random string of characters which is an item attribute not its identifier. ${ }^{79}$

In this way, one reconsideration of practice led to a more ordered and considered way of constructing reference codes (albeit within a traditional model), the other led to the conceptualisation of a difference between unique identifier and item attribute. Is this an expression of the sort of difference 'going digital' can make to archivists' understanding of the description they undertake? I offer no final verdict and return to the position that it does not really matter whether it is the archivists or the computers who are controlling and driving the action (of, in this case 
reconsidering and innovating in practice). It is possible to come to the conclusion that one of these reconsiderations (that of Green more in response to the computer) is the more radical, but surely all this tells us is that, whereas computers may have widened the horizons of the possible, it remained the archivists who decided what 'going digital' could, should and did mean for their descriptive practice.

\section{Conclusion}

This paper has constructed a skeleton chronology of the computerisation of archival description within the United Kingdom. Considering a period from the 1960s to the early 1990s it has outlined many of the early experiments and systems developed in UK archives and has sketched out how the vision of automation or 'going digital' changed over time, in line with advances and changes in the underlying technological landscape.

It has also sought to consider how archivists reacted to the challenges of the computer both in terms of a move towards co-operation and working together, but also in terms of a growing focus on the standardisation of archival description and descriptive practice. This focus on standardisation has been briefly considered and interrogated through the interconnected lenses of both; a power struggle - the reassertion of professional (human) standards in a move towards specifying requirements required by the machines; and the reconsideration of practice. It has been suggested that the answer as to the exact balance of power between archivist and computer probably remains mute, particularly in respect of the exact impact of the computer on driving changes in archivists' thinking around their descriptive practice. It concludes though that, even so, the future of this practice is still very much ours to shape. 
1 Jones, “Annual Conference, Newcastle-upon-Tyne," 491.

2 Jones, "Annual Conference, Newcastle-upon-Tyne," 491.

3 "Annual General Meeting 1964,"41. It lies outside the scope of this article, but it is worth noting that those archivists present at the presentation in 1964 immediately saw the digital preservation implications of the computer. For example, following Mr Taylor's talk; 'Miss Darlington [...] asked if the preservation on tape of material of historical or sociological importance had been considered as a long-term archive problem as distinct from an administrative one' and 'Mr I E Gray, County Archivist of Gloucester, referred to the continuous introduction of new types of computers, and asked if he would require a museum of out-of-date computers to be able to use all his magnetic tapes'. Ibid.

${ }^{4}$ Roads, "Film as Historical Evidence," 186-187.

${ }^{5}$ Cook, McDonald and Welch, "The management of records," 417.

6 "Annual general meeting, 1969", 86. His presentation was later published, see Darwin "The use of the computer".

7 Darwin, "The use of the computer," 224.

8 Ibid.

9 lbid., 219.

${ }^{10}$ Ibid., 223. This sounds like a fairly modern outlook, but it is important to temper that impression by noting that Darwin also held more traditional notions about users, writing that 'I do not consider genealogical searching of first rate importance' but considering that 'the case if the searcher is a demographer doing family reconstitution or a historical geographer wishing to deal with problems of land usage over a large area: in these cases serious scholarship can be facilitated by our taking a rather more progressive attitude towards improvements in our information retrieval systems'. Ibid.

${ }_{11}$ Darwin, "The use of the computer," 220.

12 Ibid., 227.

13 Newton, "Notes and news," 234.

${ }^{14}$ Cook, The Management of Information, 159.

15 Simmons, Bell and Roper, "PROSPEC."

${ }^{16}$ Chalmers, "Computer Indexing in the public record office."

17 Ibid., 404.

${ }^{18}$ Roper, "Computer applications committee," 101.

${ }^{19}$ Ibid.

20 Ibid., 101.

${ }^{21}$ Ibid., 101.

22 lbid., 102.

${ }^{23}$ Ibid., 103.

${ }^{24}$ Ibid., 103.

25 Ibid., 105.

${ }^{26}$ Ibid., 105.

${ }^{27}$ Bond et al., "Notes and news," 466.

${ }^{28}$ Watson, "Notes and news," 116-7.

${ }^{29}$ Underwood, "A computer index."

30 Patch, "Records management in Dyfed."

31 Butler and Nicholson, "ARMS."

${ }^{32}$ The volume also details a number of applications in use in other countries, e.g. NARS A-1, SPINDEX, SELGEM and PARADIGM in the USA, MISTRAL in the Ivory Coast. It also gives details of a records management system (CMF) in use at the University of Liverpool.

${ }^{33}$ Cook, Archives and the Computer, 10. (First edition)

34 Ibid., 15-16.

35 Ibid., 17.

${ }^{36}$ Ibid., 41-44.

37 Ibid., 54. 
38 Ibid., 100. This statement needs to be modified by another in the 1982 survey that 'The last practical applications of that package are due to be closed down early in 1983, on the introduction of new and incompatible hardware.' Bartle and Cook, Computer Applications in Archives, 1.

${ }^{39}$ Cook, Archives and the Computer, 109. (Second edition)

40 lbid., 81.

${ }^{41}$ Ibid., 83-96.

42 Ibid., 104; Woolgar, "The Wellington papers database."

${ }^{43}$ Woolgar, "The Wellington papers database," 4-5.

${ }^{44}$ Cook, Archives and the Computer, 109.

${ }^{45}$ Cook, The Management of Information, 160.

${ }^{46}$ In a report of the 1987 Annual General Meeting of the Society of Archivists, it is noted that, 'Council had accepted a recommendation by the Computer Applications Committee that it be wound up. A Computer Users Group had been established instead, the articles of which had now been approved by Council.' "Annual general meeting," 228.

${ }^{47}$ Chell, Directory of computer applications, 4.

48 Ibid., 5, 6, 9.

${ }^{49}$ Hogarth and Martin, A survey of automated practice.

50 Ibid., 1.

51 Ibid.

52 lbid., 5, 7.

${ }^{53}$ Kitching, "The impact of computerization," 4.

${ }^{54}$ Ibid.

55 Sheppard, "Annual conference, 1979," 249.

${ }^{56}$ Roper, "Computer applications committee," 105-106.

${ }^{57}$ Bell, "An archivists' co-operative?" 149. Reporting on the Conference, Elizabeth Stazicker noted that the paper 'evinced a rather disappointing immediate response, in that the emphasis of discussion fell upon the least original of the three suggested areas for cooperative effort, the purchase of conservation materials.' Stazicker, "Annual conference, 1974."

58 Roper, PROSPEC-SA, 15.

${ }^{59}$ Welch and Cooper, "Notes and news," 335.

${ }^{60}$ Bond et al, "Notes and news," 466.

$61 \mathrm{lbid}$.

62 Hogarth and Martin, A survey of automated practice, 10.

$63 \mathrm{lbid}$.

${ }^{64}$ Cottrell, “Annual conference, 1975,” 272.

${ }^{65}$ Cook and Grant, A manual of archival description, 27.

${ }^{66}$ Kitching, "The impact of computerization," 33.

${ }^{67}$ Ibid. 4.

${ }^{68}$ Roper, "Computer applications committee," 104.

69 lbid.

70 Ibid.

${ }^{71}$ Cook, "Electronic records, paper minds."

72 Williams, "The construction and allocation."

73 Green, "Reference codes."

${ }^{74}$ Williams, "The construction and allocation," 86; Hogarth and Martin, A survey of automated practice, 4.

${ }^{75}$ Williams, "The construction and allocation," 92.

76 Ibid., 92.

77 Green, "Reference codes," 145.

78 Ibid., 144, 145.

79 Ibid., 146.

"Annual general meeting." Journal of the Society of Archivists 8, no.3 (1987): 227-230. doi: 10.1080/00379818709514327

Bartle, Rachel and Michael Cook. Computer Applications in Archives: A Survey. Liverpool: Archives Unit, University of Liverpool, 1983. 
Bell, Lionel. “An archivists' co-operative?" Journal of the Society of Archivists 5, no.3 (1975): 149-157. doi: 10.1080/0037981750951404.

Bond, Maurice, P. I. King, A. Newman and Rosemary Collier. "Notes and news." Journal of the Society of Archivists 5, no.7 (1977): 466-474. doi: 10.1080/0037981770951408

Butler, D. J., and W. H. Nicholson. "ARMS - a computer-based records management system developed by Tyne and Wear County Council." Journal of the Society of Archivists 6, no.4 (1979): 200-208. doi: 10.1080/00379817909514141

Chell, Robert. Directory of computer applications in archives. London: The Society of Archivists, 1992.

Cook, Michael. Archives and the Computer. 1st ed. London: Butterworths, 1980.

Cook, Michael. Archives and the Computer. $2^{\text {nd }}$ ed. London: Butterworths, 1986.

Cook, Michael and Kristina Grant. A Manual of Archival Description. London: Society of Archivists, 1986.

Cook, Michael, L. J. McDonald and Edwin Welch. "The Management of Records' Journal of the Society of Archivists 3, no.8 (1968): 417-423. doi: 10.1080/00379816509513893

Cook, Michael. The Management of Information from Archives. Aldershot: Gower, 1986.

Cook, Terry. "Electronic Records, Paper Minds: The Revolution in Information Management and Archives in the Post-Custodial and Post-Modernist Era." Archives and Manuscripts 22, no.2 (1994): 300-329.

Cottrell, Elizabeth. "The society's chronicle: Annual conference, 1975." Journal of the Society of Archivists 5, no.4 (1975): 272-273. doi: 10.1080/0037981750951405

Chalmers, Duncan. "Computer Indexing in the public record office." Journal of the Society of Archivists 6, no.7 (1981): 399-413. doi: 10.1080/00379818109514174

Darwin, Kenneth. "The use of the computer in indexing records." Journal of the Society of Archivists 4, no.3 (1971): 218-229. doi: 10.1080/00379817109513959.

Green, Adam. "Reference codes and computer-based systems." Journal of the Society of Archivists 11, no.4 (1990): 144-146. doi: 10.1080/00379819009511645.

Hogarth, Jennifer and Gillian Martin. A survey of automated practice in selected record offices and other archive units. London: Archives Research Unit, School of Library, Archives and Information Studies, 1993.

Jones, Philip, "The society's chronicle; Annual conference, Newcastle-upon-Tyne 10th and $11^{\text {th }}$ April 1964." Journal of the Society of Archivists 2, no.10 (1964): 490-491. doi: 10.1080/00379816009513799

Kitching, Christopher. The impact of computerization on archival finding aids: A RAMP Study. Paris: UNESCO, 1991.

Newton, Carl. "Notes and news." Journal of the Society of Archivists 4, no.3 (1971): 234-238. doi: 10.1080/0037981710951396

Patch, Maureen. "Records management in Dyfed." Journal of the Society of Archivists 6, no.4 (1979): 209-213. doi: 10.1080/00379817909514142

Roads, Christopher. "Film as historical evidence." Journal of the Society of Archivists 3, no.4 (1966): 183-191. doi: 10.1080/00379816509513842

Roper, Michael. "Computer applications committee: A consultation document." Journal of the Society of Archivists 5, no.2 (1974): 101-109. doi: 10.1080/0037981740951403

Roper, Michael. PROSPEC-SA: Pilot Project : the development of PROSPEC for wider use in providing guides to record offices: final report covering the period March 1977 to September 1978. London: British Library, 1978.

Sheppard, Julia. "The society's chronicle: Annual conference, 1979." Journal of the Society of Archivists 6, no.4 (1979): 247-250. doi: 10.1080/00379817909514148

Simmons, P., Lionel Bell and Michael Roper. "PROSPEC: A Computer Application for the Public Record Office." Journal of the Society of Archivists 4, no.5 (1972): 423-427. doi: $10.1080 / 00379817209513985$ 
Stazicker, Elizabeth. "The society's chronicle: Annual conference, 1974." Journal of the Society of Archivists 5, no.2 (1974) 140-141. doi: 10.1080/0037981740951404

“The Society's Chronicle Annual General Meeting 1964." Journal of the Society of Archivists 3, no.1 (1965): 40-41. doi: 10.1080/00379816509513812

"The Society's Chronicle: Annual general meeting, 1969." Journal of the Society of Archivists 4, no.1 (1970): 85-86. doi: 10.1080/0037981700951394

Underwood, M.G. "A computer index for the archives of St John's College, Cambridge: A progress report." Journal of the Society of Archivists 6, no.4 (1979): 214-218. doi: 10.1080/00379817909514143

Watson, Andrew. "Notes and news." Journal of the Society of Archivists 6, no.2 (1978): 115-119. doi: 10.1080/00379817809514122

Welch, Edwin and C. R. H. Cooper. "Notes and news." Journal of the Society of Archivists 4, no.4 (1971) 333-336, DOI: 10.1080/00379817109513972

Williams, Gareth Haulfryn. "The construction and allocation of reference codes: A starting point for discussion." Journal of the Society of Archivists 11, no.3 (1990): 85-94. doi:10.1080/00379819009511634.

Woolgar, C M. "The Wellington papers database: An interim report." Journal of the Society of Archivists 9, no.1 (1988): 1-20. doi: 10.1080/00379818809511572 